\title{
Aphasia assessment: impact of material on naming performance
}

\author{
Avaliação da afasia: impacto do material no desempenho da nomeação \\ José FONSECA', Filipa de MIRANDA ${ }^{1,2}$, Gabriela LEAL ${ }^{1,2}$, Teresa PINHO E MELO², Isabel Pavão MARTINS 1,2
}

\begin{abstract}
Background: Naming and lexical retrieval difficulties are common symptoms of aphasia. Naming abilities are usually evaluated by means of real objects or pictures or line drawings that are printed. Objective: The aim of this study was to investigate whether the ability to name objects among individuals with aphasia is influenced by the dimensions of the visual stimuli and to understand whether the order of presentation of the stimuli, number of years of education and length of time post-onset are involved in the success of naming. Methods: The naming abilities of healthy controls and patients with acute or chronic aphasia due to stroke were assessed through presentation of two sets of 24 stimuli consisting of real objects and color photographs of the same objects presented on a screen. The results obtained under these two conditions were compared by means of within-subject paired ANOVA, controlling for presentation order. Results: 40 patients (62.4 \pm 17.3 years old; $70 \%$ females; mean education level of $8.5 \pm 5.3$ years; and $60 \%$ evaluated within the first eight days after stroke) and 50 controls that were age, gender and education-matched were included. Object naming was significantly better than naming color photographs among the patients $(p=0.001)$, but no differences were observed among the controls. Age, education, length of time postonset and presentation sequence did not have any impact on naming performance. Conclusion: These results suggest that use of digital color photographs for naming objects in assessment of aphasia may be associated with lower naming performance, compared with use of real objects. This needs to be taken into account when different forms of stimuli are presented in sequential aphasia evaluations.
\end{abstract}

Keywords: Aphasia; Language Tests; Neuropsychological Tests.

\section{RESUMO}

Antecedentes: As dificuldades de nomeação e de evocação lexical são sintomas comuns de afasia. A nomeação é geralmente avaliada por objetos reais, imagens ou desenhos de contorno, impressos. Objetivo: Este estudo visa investigar se a capacidade de nomear objetos em pessoas com afasia é influenciada pelas dimensões dos estímulos visuais e compreender se a ordem de apresentação dos estímulos, os anos de escolaridade e o tempo de evolução estão envolvidos no sucesso da nomeação. Métodos: A nomeação de pessoas saudáveis e pessoas com afasia, em fase aguda ou crónica, por AVC foi avaliada com dois conjuntos de 24 estímulos, objetos reais e fotografias a cores, dos mesmos objetos, apresentadas num ecrã. Os resultados obtidos nas duas condições foram comparados por uma ANOVA para amostras emparelhadas, controlando para a ordem de apresentação. Resultados: Foram incluídos 40 sujeitos com afasia (62,4£17,3 anos de idade, $70 \%$ mulheres, com uma escolaridade média de 8,5 $\pm 5,3$ anos, $60 \%$ avaliados nos primeiros 8 dias após o acidente vascular cerebral) e um grupo de controlo de 50 pessoas saudáveis, emparelhadas para a idade, sexo e escolaridade. A nomeação de objetos foi significativamente melhor do que a nomeação de fotografias a cores $(p=.001)$, mas isso não se verificou nos controles. A idade, a escolaridade, o tempo de evolução e a sequência de apresentação não tiveram impacto na nomeação dos dois tipos de estímulos. Conclusão: Estes resultados sugerem que a utilização de fotografias digitais a cores para avaliar a nomeação de objetos na afasia pode ser associada a um pior desempenho quando comparada com objetos reais. Isto deve ser tido em conta quando são apresentadas diferentes formas de estímulos nas reavaliações.

Palavras-chave: Afasia; Testes de Linguagem; Testes Neuropsicológicos.

\section{INTRODUCTION}

The ability to retrieve names is one of the most sensitive measurements for assessing language ${ }^{1}$ and is one that tends to persist during follow-ups on language disorders ${ }^{1}$. These impairments contribute to the differential diagnosis of the subtypes of aphasia, together with oral comprehension, oral production (speech fluency) and repetition failures.

\footnotetext{
${ }^{1}$ Universidade de Lisboa, Faculdade de Medicina, Centro de Estudos Egas Moniz, Laboratório de Estudos de Linguagem, Lisboa, Portugal.

${ }^{2}$ Centro Hospitalar Universitário de Lisboa Norte, Serviço de Neurologia, Lisboa, Portugal.

JF (iD https://orcid.org/0000-0003-2907-8103;FM (iD https://orcid.org/0000-0002-9658-085X; GL (iD https://orcid.org/0000-0001-5181-3421;

TPM (D) https://orcid.org/0000-0002-0375-0101; IPM (D) https://orcid.org/0000-0002-9611-7400

Correspondente:José Fonseca; Email:jfonseca@medicina.ulisboa.pt.

Conflict of interest: There is no conflict of interest to declare.
}

Authors' contributions: All authors made substantial contributions to the design of the study; to collection, analysis and interpretation of data; to writing the paper; and to approval of the final version.

Received on August 17, 2020; Received in its final form on November 17, 2020; Accepted on December 05, 2020. 
Naming a pictured or a real object is a complex process and involves a number of relatively distinct cognitive processes and mental representations ${ }^{2,3}$. Firstly, it requires recognition of the visual stimulus as an instance of a familiar concept. The meaning of the stimulus then has to be accessed in a long-term semantic memory representation. Activation of its lexical representation, among possible competing alternatives, is also required. Retrieval of the exact phonological word form takes place, followed by activation of the motor program and effective articulation, thus leading to word production ${ }^{4}$. There is evidence that these processes seem to be somehow interactive ${ }^{5}$.

The representations and processes underlying naming may thus be hampered at different levels in patients with brain lesions, thereby leading to distinct patterns of performance. Patients may have difficulties at the visual recognition level, with an agnosic type of behavior, such that they are unable to match drawings of objects, or to recognize partial drawings or objects presented from an unusual perspective. Some other patients may access the structural visual description but cannot access the lexical-semantic stores and might perform poorly in semantic tasks or might produce semantic paraphasia. Still others cannot retrieve the phonological word form, thus presenting the tip-of-the-tongue phenomenon, with pauses, phonological errors or attempts to name by using successive conduites d'approche. Therefore, both the success of naming and the type of errors produced can be informative about the impaired cognitive processes and give cues for language rehabilitation.

As a rule, naming tests for aphasia or cognitive assessment consist of presentation of real objects (Lisbon Aphasia Assessment Battery (BAAL) ${ }^{6}$ or line drawings of objects, actions or other stimuli (body parts, food, etc.) ${ }^{7,89,10}$. However, these types of stimuli may not be suitable for certain clinical contexts such as bedside assessment or emergency situations (before endovascular treatments or thrombolysis) in which clinicians need to have quick access to images that can be presented. Nowadays, this is easily achieved through accessing images on a smartphone or tablet. The same occurs during distant assessment of aphasia, particularly when there is risk of infection, such as during the COVID-19 pandemic. Therefore it is relevant to know which types of stimuli are more appropriate and to what extent they impact on the subject's performance.

It is well recognized that the ability to retrieve a name is related to several variables, comprising word frequency, stimulus familiarity, degree of abstraction or imageability, age at acquisition and recency ${ }^{11}$. Moreover, the color and the number of visual dimensions (two or three) are involved. Studies on healthy individuals have shown that 2D, 3D and colored images may be treated differently in the brain, particularly among subjects with low levels of literacy ${ }^{12,13,14}$. However, to the best of our knowledge, no comparative studies have been conducted among people with aphasia, between objects in two and three dimensions.

The aim of this study was to investigate whether the ability to name objects among individuals with aphasia is influenced by the dimensions of the visual stimuli, through comparing real objects with digitally presented color photographs. Additionally, it was sought to understand which clinical variables are involved in success in naming, such as the order of presentation of the stimuli, number of years of formal education and length of time post-onset.

\section{METHODS}

\section{Study design}

This was a prospective cross-sectional observational study comparing the accuracy of naming performance between individuals with aphasia and controls, with regard to two types of colored visual stimuli.

\section{Population}

\section{Clinical sample}

The subjects were consecutive patients with aphasia due to stroke who were admitted to a stroke unit or who were undergoing speech therapy, in a university hospital.

\section{Patient inclusion and exclusion criteria}

The patients included presented the following characteristics: diagnosis of aphasia, either in the acute or in the chronic stage; age above 18 years; ability to cooperate in the evaluation; and ability to provide informed consent in person or through a caregiver. The following exclusion criteria were used: poor cooperation; visual impairment; absence of speech or speech reduced to a stereotype; or a previous (before stroke) or current diagnosis of dementia. The diagnosis of aphasia was clinical among the acute patients and was made by acute-care neurologists during bedside examination and through use of the National Institutes of Health Stroke Scale ${ }^{15}$. For chronic patients attending the speech therapy department, their diagnosis was supported by speech therapists and was quantified though the BAAL ${ }^{6}$, which is the national goldstandard instrument for aphasia assessment in Portugal.

\section{Controls}

Individuals above 18 years of age, with no history of neurological or psychiatric illness and with a Mini-Mental State Examination ${ }^{16}$ score within the normal values for age and education, were included as a control group.

All participants or, in the case of patients with aphasia, their caregivers, gave written informed consent in accordance with the Declaration of Helsinki. The study was approved by the Ethics Committee of the Academic Center of Medicine of Lisbon. 


\section{Procedures}

All participants, with aphasia and controls, were assessed by the same evaluator (JF), through two oral naming tasks of 24 items each. These tasks consisted of naming a set of common real objects and a set of digital color photographs of the same objects that were presented in standard views on the screen of a tablet. The stimuli were selected from a wider set by an evaluation panel (of speech therapists, psychologists and neurologists), taking into account the quality of the photograph, difficulty/familiarity of the stimulus and word frequency. The word frequency of the items selected was determined in accordance with a written frequency scale for the European Portuguese Language, consisting of 12 levels $^{17}$. The items selected belong to levels 4 (16.7\%), 5 (41.7\%), 6 (25\%) and $7(16.7 \%)$ of this scale, which represent medium-to-high frequency of the use of nouns in European Portuguese. Level 1 on this scale consists of the lowest-frequency words and level 12, the highest-frequency words (grammatical items).

The objects and photographs were displayed one by one, always following the same order. The sequence of presentation, i.e. real objects followed by photographs or photographs followed by real objects, was randomized to control for learning. An interference task was applied between the two sets, consisting of a spontaneous speech production test. The participants' responses were audiotaped for analysis. No aids were provided, and no touching of objects was allowed. The participants' first response was quoted, and the evaluator did not provide any feedback during application of the test.

\section{Statistical analysis}

We used descriptive statistics to characterize the continuous variables of age, education level and test scores (using the mean or median, with standard deviation or interquartile range) and to describe the categorical variables of gender and case type (acute or chronic) (using percentages). The naming scores from the real objects and the photographs were compared by means of Student's t test. ANOVA for repeated measurements was used to investigate the difference between the two tasks, controlled for presentation order. Multiple linear regression, using the enter method, was carried out to evaluate the effects of age, education level and length of time poststroke onset, on each naming score. Results were considered significant when $p<0.05$. The statistical analysis was performed using the Statistical Package for the Social Sciences software (version 24.0) $)^{18}$.

\section{RESULTS}

A total of 40 subjects with aphasia (12 men), with an average age of 62.4 years and 8.5 years of education were included (Table 1). The majority had suffered ischemic stroke $(\mathrm{N}=33)$. Twenty-four patients were observed within the first eight days and 16 were observed in the chronic period after stroke. Apart from the length of time post-stroke onset, there were no significant differences between the acute and chronic patients in terms of age, gender, education level or type of stroke, or in their performance in each of the naming tasks (Table 2).

The control group consisted of 50 subjects who were matched for age, gender and education with the participants with aphasia, as depicted in Table 1. The controls performed at ceiling levels and outperformed the participants with aphasia in both naming tests (Table 1).

The participants with aphasia obtained a significantly higher score through naming the objects than through naming the photographs $(\mathrm{t}=3.720(39) ; p=0.001)$ (Table 3). No difference was found among the controls. A more detailed analysis on the patients' performance revealed that only two out of the total of 24 items presented a significant difference between the two types of stimulus. These consisted of a mirror $(\mathrm{F}=11.323 ; p=0.002)$ and glasses $(\mathrm{F}=4.944 ; p$

Table 1. Demographic data and total scores obtained among patients and controls.

\begin{tabular}{|c|c|c|c|c|c|}
\hline & $\begin{array}{l}\text { Control subjects } \\
\qquad(\mathrm{N}=50)\end{array}$ & $\begin{array}{l}\text { Aphasia patients } \\
\qquad(\mathrm{N}=40)\end{array}$ & Test & $p$ & $95 \% \mathrm{Cl}$ \\
\hline $\begin{array}{l}\text { Age (years) mean } \pm \text { SD } \\
\text { (range) }\end{array}$ & $\begin{array}{c}67.3 \pm 15.7 \\
(24-89)\end{array}$ & $\begin{array}{l}62.4 \pm 17.3 \\
(24-91)\end{array}$ & -1.405 & $p=n s$ & $-11,962 ; 2,062$ \\
\hline $\begin{array}{l}\text { Education level (years) mean } \\
\pm \mathrm{SD}\end{array}$ & $8.1 \pm 4.8$ & $8.5 \pm 5.3$ & 0.372 & $p=n s$ & $-1.738 ; 2.538$ \\
\hline $\begin{array}{l}\text { Education level (years) } \\
0-6(\%) \\
>6(\%)\end{array}$ & $\begin{array}{l}25(50.0 \%) \\
25(50.0 \%)\end{array}$ & $\begin{array}{l}21(52.5 \%) \\
19(47.5 \%)\end{array}$ & $\gamma^{2}=0.056$ & $p=n s$ & $0.481 ; 2.540$ \\
\hline $\begin{array}{l}\text { Gender } \\
\mathrm{M}(\%) \\
\mathrm{F}(\%)\end{array}$ & $\begin{array}{l}14(28 \%) \\
36(72 \%)\end{array}$ & $\begin{array}{l}12(30 \%) \\
28(70 \%)\end{array}$ & $\gamma^{2}=0.043$ & $p=n s$ & $0.441 ; 2.753$ \\
\hline $\begin{array}{l}\text { Objects score mean } \pm \text { SD } \\
(\max =24)\end{array}$ & $24.0 \pm 0.0$ & $15.8 \pm 7.6$ & -6.813 & $p=0.000$ & $-10.602 ;-5.748$ \\
\hline $\begin{array}{l}\text { Photographs score mean } \pm \text { SD } \\
(\max =24)\end{array}$ & $23.9 \pm 0.4$ & $14.0 \pm 7.3$ & -8.596 & $p=0.000$ & $-12.291 ;-7.609$ \\
\hline
\end{tabular}

$\mathrm{Cl}$ : confidence interval; ns: not significant; M: Male; F: Female. 
$=0.032)$ (Table 4). Nonetheless, the overall score difference remained after eliminating these two items. Presentation order (objects-photographs or photographs-objects) was not associated with differences in naming scores (Table 5).

Multiple linear regression was applied to create a model for predicting naming abilities among individuals with aphasia, based on the independent variables of age, number of years of formal education, length of time post-onset and stimulus order. However, the model had low predictive value and none of the independent variables was significantly associated with performance regarding naming of objects $(\mathrm{F}(4)=$ 0.333: $\left.p=n s ; \mathrm{R}^{2}=0.037\right)$ or colored photographs $(\mathrm{F}(4)=0.586$ : $\left.p=n s ; \mathrm{R}^{2}=0.063\right)$.

Table 2. Demographic data, clinical data and total scores: comparison between the length of time post-onset.

\begin{tabular}{|c|c|c|c|}
\hline & $\begin{array}{c}\text { Acute } \\
\text { ( } \leq 8 \text { days })\end{array}$ & $\begin{array}{l}\text { Chronic } \\
\text { (>8 days) }\end{array}$ & Statistic \\
\hline N & 24 & 16 & \\
\hline Age (years) mean $\pm S D$ & $65.8 \pm 16.0$ & $57.2 \pm 18.4$ & $p=n s$ \\
\hline $\begin{array}{l}\text { Education level (years) mean } \\
\pm \mathrm{SD}\end{array}$ & $7.4 \pm 5.2$ & $10.2 \pm 5.0$ & $p=n s$ \\
\hline $\begin{array}{l}\text { Education level (years) } \\
0-6(\%) \\
>6(\%)\end{array}$ & $\begin{array}{l}15(62.5 \%) \\
9(37.5 \%)\end{array}$ & $\begin{array}{c}6(37.5 \%) \\
10(62.5 \%)\end{array}$ & $p=n s$ \\
\hline $\begin{array}{l}\text { Gender } \\
\mathrm{M}(\%) \\
\mathrm{F}(\%)\end{array}$ & $\begin{array}{c}8(33 \%) \\
16(66 \%)\end{array}$ & $\begin{array}{c}4(25 \%) \\
12(75 \%)\end{array}$ & $p=n s$ \\
\hline $\begin{array}{l}\text { Length of time post-onset } \\
\text { (days) mean } \pm \text { SD }\end{array}$ & $3.9 \pm 2.2$ & $517.4(717.1)$ & $t=3.531(38) ; p=0.001$ \\
\hline $\begin{array}{l}\text { Stroke } \\
\text { Ischemic (\%) } \\
\text { Hemorrhagic (\%) }\end{array}$ & $21: 2$ & $12: 3$ & $p=n s$ \\
\hline $\begin{array}{l}\text { Objects score mean } \pm \text { SD } \\
(\max =24)\end{array}$ & $16.1 \pm 7.9$ & $15.4 \pm 7.3$ & $p=n s$ \\
\hline $\begin{array}{l}\text { Photographs score mean } \pm S D \\
(\max =24)\end{array}$ & $13.7 \pm 7.7$ & $14.3 \pm 6.9$ & $p=n s$ \\
\hline Stimulus total & $29.8 \pm 15.2$ & $29.8 \pm 14.1$ & $p=n s$ \\
\hline
\end{tabular}

ns: not significant; M: Male; F: Female.

Table 3. Comparison of performance achieved by the controls and the patients with acute or chronic aphasia in the two naming tasks (repeated-measurement ANOVA).

\begin{tabular}{|c|c|c|c|c|c|}
\hline Group & $\mathrm{N}$ & $\begin{array}{c}\text { Objects } \\
\text { Mean } \pm \text { SD; median }\end{array}$ & $\begin{array}{c}\text { Photos } \\
\text { Mean } \pm \text { SD; median }\end{array}$ & $F$ & $\mathrm{P}$ \\
\hline Controls & 50 & $24.0 \pm 0.0 ; 24$ & $23.9 \pm 0.4 ; 24$ & 3.769 & 0.06 \\
\hline $\begin{array}{l}\text { Patients with } \\
\text { aphasia }\end{array}$ & 40 & $15.83 \pm 7.59 ; 18.50$ & $13.95 \pm 7.31 ; 15.00$ & 13.836 & 0.001 \\
\hline Acute aphasia & 24 & $16.1 \pm 7.9$ & $13.7 \pm 7.7$ & 9.803 & 0.005 \\
\hline Chronic aphasia & 16 & $15.8 \pm 7.6$ & $14.0 \pm 7.3$ & 4.765 & 0.045 \\
\hline
\end{tabular}

Table 4. Comparison between objects and photos by means of ANOVA for repeated measurements.

\begin{tabular}{|c|c|c|c|c|}
\hline Stimulus & $\begin{array}{c}\text { Objects } \\
\text { Mean } \pm \text { SD; median }\end{array}$ & $\begin{array}{c}\text { Photos } \\
\text { Mean } \pm \text { SD; median }\end{array}$ & $\mathrm{F}$ & $P$ \\
\hline Pencil & $0.78 \pm 0.42 ; 1.0$ & $0.68 \pm 0.47 ; 1.0$ & 2.053 & 0.160 \\
\hline Pin & $0.58 \pm 0.50 ; 1.0$ & $0.40 \pm 0.50 ; 0.0$ & 3.468 & 0.70 \\
\hline Match & $0.73 \pm 0.45 ; 1.0$ & $0.60 \pm 0.50 ; 1.0$ & 1.970 & 0.168 \\
\hline Hairbrush & $0.58 \pm 0.50 ; 1.0$ & $0.50 \pm 0.50 ; 0.5$ & 0.814 & 0.372 \\
\hline Coin & $0.70 \pm 0.46 ; 1.0$ & $0.68 \pm 0.47 ; 1.0$ & 0.109 & 0.743 \\
\hline Swiss switchblade/penknife & $0.58 \pm 0.50 ; 1.0$ & $0.58 \pm 0.50 ; 1.0$ & 0.000 & 1.000 \\
\hline Fork & $0.68 \pm 0.47 ; 1.0$ & $0.60 \pm 0.50 ; 1.0$ & 1.000 & 0.323 \\
\hline Scissors & $0.63 \pm 0.49 ; 1.0$ & $0.65 \pm 0.48 ; 1.0$ & 0.109 & 0.743 \\
\hline
\end{tabular}


Table 4. Cont.

\begin{tabular}{|c|c|c|c|c|}
\hline Stimulus & $\begin{array}{c}\text { Objects } \\
\text { Mean } \pm \text { SD; median }\end{array}$ & $\begin{array}{c}\text { Photos } \\
\text { Mean } \pm \text { SD; median }\end{array}$ & $\mathrm{F}$ & $\mathrm{P}$ \\
\hline Mirror & $0.75 \pm 0.44 ; 1.0$ & $0.45 \pm 0.50 ; 0.0$ & 11.323 & $0.002^{*}$ \\
\hline Perfume bottle & $0.45 \pm 0.50 ; 0.0$ & $0.45 \pm 0.50 ; 0.0$ & 0.000 & 1.000 \\
\hline Bill/banknote & $0.63 \pm 0.49 ; 1.0$ & $0.53 \pm 0.51 ; 1.0$ & 2.053 & 0.160 \\
\hline Stamp & $0.65 \pm 0.48 ; 1.0$ & $0.53 \pm 0.51 ; 1.0$ & 2.910 & 0.096 \\
\hline Spoon & $0.70 \pm 0.46 ; 1.0$ & $0.60 \pm 0.50 ; 1.0$ & 2.053 & 0.160 \\
\hline Matchbox & $0.60 \pm 0.50 ; 1.0$ & $0.58 \pm 0.50 ; 1.0$ & 0.089 & 0.767 \\
\hline Doorbell & $0.70 \pm 0.46 ; 1.0$ & $0.58 \pm 0.50 ; 1.0$ & 2.910 & 0.096 \\
\hline Pen & $0.70 \pm 0.46 ; 1.0$ & $0.55 \pm 0.50 ; 1.0$ & 3.162 & 0.083 \\
\hline Key & $0.70 \pm 0.46 ; 1.0$ & $0.58 \pm 0.50 ; 1.0$ & 1.970 & 0.168 \\
\hline Hair comb & $0.70 \pm 0.46 ; 1.0$ & $0.70 \pm 0.46 ; 1.0$ & 0.000 & 1.000 \\
\hline Clock & $0.68 \pm 0.47 ; 1.0$ & $0.60 \pm 0.50 ; 1.0$ & 1.295 & 0.262 \\
\hline Glasses & $0.78 \pm 0.42 ; 1.0$ & $0.63 \pm 0.49 ; 1.0$ & 4.944 & $0.032^{*}$ \\
\hline Glass cup & $0.70 \pm 0.46 ; 1.0$ & $0.73 \pm 0.45 ; 1.0$ & 0.109 & 0.743 \\
\hline Clothespin/clothes peg & $0.55 \pm 0.50 ; 1.0$ & $0.45 \pm 0.50 ; 0.0$ & 2.053 & 0.160 \\
\hline Teacup & $0.65 \pm 0.48 ; 1.0$ & $0.70 \pm 0.46 ; 1.0$ & 0.281 & 0.599 \\
\hline Lightbulb & $0.68 \pm 0.47 ; 1.0$ & $0.65 \pm 0.48 ; 1.0$ & 0.089 & 0.767 \\
\hline Total without mirror/glasses & $14.30 \pm 7.02 ; 16.50$ & $12.88 \pm 6.66 ; 14.0$ & 9.215 & 0.004 \\
\hline
\end{tabular}

Table 5. Demographic data, clinical data and total scores: comparison between education levels.

\begin{tabular}{|c|c|c|c|}
\hline & $\begin{array}{l}\text { Education level } \\
\leq 6 \text { years }\end{array}$ & $\begin{array}{c}\text { Education level } \\
>6 \text { years }\end{array}$ & Statistic \\
\hline $\mathrm{N}$ & 21 & 19 & \\
\hline Age (years) mean $\pm S D$ & $66.5 \pm 17.9$ & $57.7 \pm 15.8$ & $p=n s$ \\
\hline $\begin{array}{l}\text { Education level (years) } \\
\text { mean } \pm \text { SD }\end{array}$ & $4.1 \pm 1.2$ & $13.4 \pm 3.1$ & $\begin{array}{c}t=-12.983(38) \\
p=0.000\end{array}$ \\
\hline $\begin{array}{l}\text { Gender } \\
\mathrm{M}(\%) \\
\mathrm{F}(\%)\end{array}$ & $\begin{array}{c}9(43 \%) \\
12(57 \%)\end{array}$ & $\begin{array}{c}3(16 \%) \\
16(84 \%)\end{array}$ & $p=n s$ \\
\hline $\begin{array}{l}\text { Length of time post-onset } \\
\text { (days) mean } \pm \text { SD }\end{array}$ & $35.6 \pm 88.7$ & $401.3 \pm 697.4$ & $\begin{array}{c}t=-2.385(38) \\
p=0.022\end{array}$ \\
\hline $\begin{array}{l}\text { Stroke } \\
\text { Ischemic (\%) } \\
\text { Hemorrhagic (\%) }\end{array}$ & $\begin{array}{c}20(95 \%) \\
1(5 \%)\end{array}$ & $\begin{array}{c}13(68 \%) \\
4(21 \%)\end{array}$ & $p=n s$ \\
\hline $\begin{array}{l}\text { Objects score mean } \pm S D \\
(\max =24)\end{array}$ & $14.6 \pm 7.6$ & $17.2 \pm 7.5$ & $p=n s$ \\
\hline $\begin{array}{l}\text { Photographs score mean } \pm S D \\
(\max =24)\end{array}$ & $12.4 \pm 6.9$ & $15.7 \pm 7.6$ & $p=n s$ \\
\hline
\end{tabular}

ns: not significant; M: Male, F: Female.

\section{DISCUSSION}

In this study, we found that the performance of people with aphasia was superior in naming real objects than in naming color photographs of the same objects presented on a screen, regardless of the length of time post-onset and education level of the subjects. This demonstrates the importance of object dimension, and of presentation type (real versus virtual), in aphasia testing.
Damásio et al. (1979) ${ }^{19}$, through comparing the naming of real objects and black and white drawings, and Reis et al. $(2006)^{14}$, through comparing color and black and white photographs, demonstrated that color can influence the visual perception of the stimuli. Furthermore, specific difficulty in naming 2D stimuli was described among healthy subjects with low education levels ${ }^{13}$. Reis et al. ${ }^{6}$ argued that formal education was important in the cognitive process involved in processing two-dimensional but not three-dimensional 
representations of common objects, thus indicating that education influences the visual system or the interaction between the visual and the language systems.

However, in the present study, and in the particular context of aphasia, education level was not a predictor of performance. This means that in individuals with aphasia there may be other factors involved, i.e. the severity of aphasia or the extent of brain lesions. This may be particularly relevant for objects that are difficult to represent in two dimensions, such as a mirror or glasses, which might be more difficult to recognize in a picture. Nevertheless, the present results could not be explained solely on the basis of those two items, given that the final score difference remained when they were removed. Moreover, the healthy controls performed at the ceiling level in the photograph task.

Aphasia due to stroke corresponds, in the large majority of cases, to lesions in the region of the middle cerebral artery. This tends to spare the brain areas responsible for the earliest levels of visual processing, in the occipital lobe, which depends on the posterior cerebral artery. The current anatomical model of language organization postulates that there are two main language processing pathways: a dorsal stream and a ventral stream. These roughly support speech programming and production and speech comprehension, respectively ${ }^{20}$. Fridriksson et al. ${ }^{21}$ analyzed the symptoms of aphasia according to this model and found that the naming abilities of people with aphasia could be predicted by the degree of damage to an extensive cortical network and did not correspond to a specific localization. However, the ventral language system gently overlaps with the visual recognition pathways and the semantic areas of the left middle and inferior temporal lobes. Hence, this system may have an impact on fine object recognition. In addition, more anterior frontal lesions may interfere with abstraction abilities, which are also required in order to infer a meaning from less ecological representation. In the future, it may be of interest to understand whether difficulty in naming 2D items is more likely to be observed in ventral than in dorsal language pathway lesions.

It is true that in many clinical situations, such as in the emergency room or at the bedside of a patient, it is easier to present different types of stimuli on a tablet or smartphone. However, only 2D stimuli that were previously tested or validated among people with aphasia should be used. The same applies when subjects with aphasia are evaluated at a distance, such as is taking place during periods of confinements or when motor impairments limit the transportation of patients to the assessment location.

We acknowledge that there were some limitations to our study, namely the small sample studied and the limited number of stimuli. Thus, we stress that there is a need to confirm these results in a larger series and in populations from different cultures. We did not include neuroimaging data and the only detailed neurolinguistic analysis (severity of aphasia and degree of syntactic impairment, for instance) came from the sample of chronic patients, which was insufficient to analyze.

Even though these results need to be confirmed in larger samples of patients from other contexts, we believe they can be useful in relation to evaluating patients with aphasia at the bedside or at a distance, with a view to taking into account the possibility that patients' naming scores from images are underestimated in comparison with testing using real objects.

In future research, it will be of interest to ascertain whether individuals' performance in naming real objects and color photographs is influenced by the lesion location and the type of aphasia.

\section{REFERENCES}

1. Rohde A, Worrall L, Godecke E, O'Halloran R, Farrell A, Massey M. Diagnostic of aphasia in stroke populations: a systematic review of language tests. Plos One. 2018 Mar 22;13(3):e0194143. https://doi. org/10.1371/journal.pone.0194143

2. Dell GS, O'Seaghdha PG. Stages of lexical access in language production. Cognition. 1992 Mar;42(1-3):287-314. https://doi. org/10.1016/0010-0277(92)90046-K

3. Levelt WJ. Spoken word production: a theory of lexical access. Proc Natl Acad Sci U S A. 2001 Nov 6;98(23):13464-71. https://doi. org/10.1073/pnas.231459498

4. DeLeon J, Gottesman RF, Kleinman JT, Newhart M, Davis C, HeidlerGary J, et al. Neural regions essential for distinct cognitive processes underlying picture naming. Brain. 2007 May;130(5):1408-22. https:// doi.org/10.1093/brain/awm011

5. Dell GS, Reich PA. Stages in sentence production: an analysis of speech error data.J Verb Learn Verb Be. 1981;20(6):611-29. https:// doi.org/10.1016/S0022-5371(81)90202-4

6. Ferro JM. Neurologia do comportamento: estudo de correlação com a tomografia axial computorizada [Doutorado]. [Lisboa]: Universidade de Lisboa, Faculdade de Medicina de Lisboa; 1986. 576p.
7. Goodglass H, Kaplan E. The assessment of aphasia and related disorders. Philadelphia (PA): Lea \& Febiger, U.S.; 1972.108 p.

8. Huber W, Poeck K, Weniger D, Willmes K. Der aachener aphasie Test. Göttingen: Hogrefe; 1983.

9. Kertesz A. Aphasia and associated disorders: taxonomy, localization and recovery. New York (NY): Grune \& Stratton; 1979.

10. Snodgrass JG, Vanderwart M. A standardized set of 260 pictures: norms for name agreement, image agreement, familiarity and visual complexity. J Exp Psychol Hum Learn. 1980 Mar;6(2):174-215. https:// doi.org/10.1037/0278-7393.6.2.174

11. Barry C, Morrison CM, Ellis AW. Naming the snodgrass and vanderwart pictures: effects of age of acquisition, frequency, and name agreement. Q J Exp Psychol-A. 1997;50A(3):560-85. https://doi. org/10.1080/027249897392026

12. Castro-Caldas A, Reis A. Neurobiological substrates of illiteracy. Neuroscientist. 2000 Dec 1;6(6):475-82. https://doi. org/10.1177/107385840000600610

13. Reis A, Petersson KM, Castro-Caldas A, Ingvar M. Formal schooling influences two- but not three-dimensional naming skills. Brain Cogn. 2001 Dec;47(3):397-411. https://doi.org/10.1006/brcg.2001.1316 
14. Reis A, Faísca L, Ingvar M, Petersson KM. Color makes a difference: two-dimensional object naming in literate and illiterate subjects. Brain Cogn. 2006 Feb;60(1):49-54. https://doi.org/10.1016/j. bandc.2005.09.012

15. National Institute of Health Stroke Scale. Wiley encyclopedia of clinical trials. Hoboken (NJ): John Wiley \& Sons, Inc; 2007.

16. Morgado J, Rocha CS, Maruta C, Guerreiro M, Martins IP. Cut-off scores in MMSE: a moving target? Eur J Neurol. 2010 May;17(5):6925. https://doi.org/10.1111/j.1468-1331.2009.02907.x

17. Bacelar do Nascimento MF, Casteleiro JM, Marques ML, Barreto F, Amaro R. (s.d.). Corlex: Léxico de frequências do português [Base lexical]. Disponivel em http://www.clul.ul.pt
18. IBM Corp. Released 2016. IBM SPSS Statistics for Windows, Version 24.0. Armonk (NY): IBM Corp.; 2016.

19. Damasio AR, McKee J, Damasio H. Determinants of performance in color anomia. Brain Lang. 1979 Jan;7(1):74-85. https://doi. org/10.1016/0093-934X(79)90007-5

20. Hickok G, Poeppel D. The cortical organization of speech processing. Nat Rev Neurosci. 2007 May;8(5):393-402. https://doi.org/10.1038/ $\operatorname{nrn} 2113$

21. Fridriksson J, den Ouden D-B, Hillis AE, Hickok G, Rorden C, Basilakos A, et al. Anatomy of aphasia revisited. Brain. 2018 Mar 1;141(3):84862. https://doi.org/10.1093/brain/awx363 